\title{
Membangun Masyarakat Berkepribadian di Bidang Kebudayaan dalam Memperkuat Jawa Tengah sebagai Pusat Kebudayaan Jawa
}

\author{
Eko Punto Hendro \\ Program Studi Antropologi Sosial Fakultas Ilmu Budaya \\ Universitas Diponegoro Semarang \\ Email: eko.ipung@gmail.com
}

\begin{abstract}
THE -- condition of the Javanese society is now more individualistic, materialistic, and more prioritizing its own interests than the common interest, the lack of tolerance towards others, wanting to get rich by justifying all means, as well as violence and crime is increasing everywhere. Aspects of power and economic aspects become very dominant in the orientation of community life, which should only be a means of living together. As a result, today's society tends to pursue wealth and power by justifying all means, ignorance, and leaving mutual cooperation and tolerance.Soekarno's trilogy program implemented by the Governor of Central Java with the addition of "ora ngapusi" and "ora korupsi" slogan, may be appreciated by the people of Central Java, especially to improve people's understanding of their adhilugung culture.
\end{abstract}

Key Words: Culture, Adhiluhung, Trilogy, Central Java, Governor

\section{Pendahuluan}

Menurut Ki Hajar Dewantara, kebudayaan adalah cipta, rasa dan karsa. Dari definisi ini dapat disimpulkan bahwa manusia adalah makhluk yang paling sempurna di dunia ini karena memiliki kebudayaan sebagai landasan perilakunya, yang tidak dimiliki makhluk hidup lainnya.Dari perspektif ilmu pengetahuan, kehadiran manusia ditandai dengan adanya kebudayaan. Kebudayaan tertua di Indonesia adalah kebudayaan dari jaman prasejarah yaitu kebudayaan batu tua (paleolitik) yang didukung oleh manusia purba Pithecantropus Erectus dari situs Sangiran dan Patiayam.Kebudayaan ini kemudian berkembang dalam kebudayaan dari jaman mesolitik, neolitik, logam hingga jaman sejarah dan jaman sekarang yang didukung oleh manusia modern dari subras Austronesia.Candi dan prasasti merupakan produk budaya dari masa sejarah awal yang diwarnai oleh kebudayaan Hindu dan Budha.Selanjutnya kebudayaan Islam juga mewarnai kebudayaan Indonesia yang dibuktikan dengan kehadiran Masjid Agung Demak dan peninggalan kebudayaan Islam lainnya. Pada jaman modern perkembangan Kebudayaan Indonesia diwarmai oleh kebudayaan barat yang diawali dari jaman VOC dan jaman kolonial yang salah satu produknya di Jawa Tengah adalah Pendopo Agung Istana Kadipaten Mangkunegaran dan gedung kesenian Sobokarti di kota Semarang, berupa bangunan Jawa dengan konstruksi modern.

Salah satu bukti yang diakui dunia sebagai warisan dunia (world heritage) di Jawa Tengah adalah Situs Sangiran yang terletak di Kabupaten Sragen, Candi Borobudur di Kabupaten Magelang, dan Candi Prambanan di Klaten. Pengakuan tersebut merupakan hal yang membanggakan. Oleh para pakar budaya dan purbakala situs Sangiran 
dinyatakan mengandung kebudayaan yang dianggap salah satu kebudayaan tertua di dunia, dan sekaligus merupakan salah satu situs manusia tertua yang ditemukan di muka bumi ini.Peralatan dari bahan batu paleolitikum yang dibuat oleh manusia Jawa dari Sangiran itu merupakan buktinya.

Jawa Tengah memiliki enam warisan budaya yang diakui dunia dalam bentuk penghargaan world heritage, tiga diantaranya bersifat kebendaan (tangible), yaitu Candi Borobudur, Candi Prambanan dan Situs Sangiran. tigaworld heritage lainnya bersifat intangible (non-kebendaan), yaitu Batik, Keris, dan Wayang. Oleh karena itu tidak berlebihan bila para pakar dan pelaku budaya menganggap bahwa Provinsi Jawa Tengah merupakan pusat Kebudayaan Jawa, sebab ke enamworld heritage tersebut juga merupakan produk-produk kebudayaan Jawa dari masa pra sejarah hingga sekarang.

Dari uraian di atas, maka pemerintah provinsi bersama-sama masyarakat Jawa Tengah dengan bahu-membahu harus menjaga kelestarian kebudayaan Jawa ini. Lebih dari pada itu juga harus mereinventarisasi, mereformulasi, dan mengaktualisasi Kebudayaan Jawa yang sudah sangat tua ini agar terus hidup dan digunakan sebagai pedoman perilaku masyarakat Jawa Tengah agar menjadi manusia-manusia yang berkarakter, berbudaya dan bermartabat dalam kehidupannya dan berkomunikasi dengan masyarakat lainnya.

Karakter masyarakat Jawa Tengah mengalami degradasi, karena sudah jauh meninggalkan nilai-nilai budaya Jawa, diantaranya terwujud dalam sikap unggah-ungguh, tepa slira, gotong royong, andap asor, semanak, sak yeg sak ekapraya sudah tidak banyak dipahami oleh orang-orang Jawa. Sikap-sikap itu sebenarnya memiliki makna kebersamaan yang tinggi di masyarakat Jawa, khususnya dalam kehidupan sosial dan saling menghargai satu sama lain. Kondisi masyarakat Jawa sekarang sudah bersifat lebih individual dan materialistis, lebih mendahulukan kepentingannya sendiri dari pada kepentingan bersama, kurangnya toleransi terhadap sesama, ingin cepat kaya walaupun orang lain tetap miskin dan menderita. Di samping itu konflik sosial, kekerasan dan kejahatan semakin meningkat di tengah-tengah masyarakat.Aspek kekuasaan dan ekonomi menjadi sangat dominan dalam orientasi kehidupan masyarakat, yang seharusnya hanyalah merupakan sarana kehidupan bersama. Akibatnya masyarakat saat ini cenderung memburu harta dan kekuasaan dengan menghalalkan segala cara, tidak peduli terhadap sesama dan lingkungan, serta meninggalkan gotong royong dan toleransi.

Globalisasi memang tidak dapat dihindari,Untuk mengantisipasi pengaruh negatif globalisasi, seharusnya pemerintah dan masyarakatmerevitalisasikebudayaan secara terus menerus. Hal ini agar kebudayaan masyarakat dapat berkembang dengan baik sesuai perkembangan jaman, dan tidak berkembang secara liar seperti kondisi saat ini.

\section{Konsep Kebudayaan}

Banyak para pakar budaya yang mendefinisikan tentang kebudayaan. Dalam tulisan ini akan dipaparkan tiga contoh, misalnya seorang antropolog dari Amerika Clifford Geertz dalam bukunya "The Interpretation of Culture", (1973) mengemukakan suatu definisi kebudayaan sebagai: (1) suatu sistem keteraturan dari makna dan simbolsimbol yang digunakan oleh individu-individu untuk mendefinisikan dunia mereka, mengekspresikan perasaan-perasaan mereka, dan membuat penilaian mereka; (2) suatu 
pola makna-makna yang ditransmisikan secara historis, yang terkandung dalam bentukbentuk simbolik yang digunakan manusia untuk berkomunikasi, memantapkan dan mengembangkan pengetahuan mereka mengenai dan bersikap terhadap kehidupan; (3) suatu peralatan simbolik untuk mengontrol perilaku; dan (4) oleh karena kebudayaan adalah suatu sustem simbol, maka proses kebudayaan harus dipahami, diterjemahkan dan diinterpretasi. Seorang arsitek juga budayawan Amos Rapopport (1969) juga mengatakan bahwa kebudayaan adalah seperangkat sistem simbol yang digunakan manusia sebagai pedoman perilaku dan strategi adaptasi.

Dari uraian di atas dapat dilihat bahwa simbol merupakan bagian terpenting dalam kebudayaan, yaitu merupakan aspek sosiologis dalam kebudayaan yang diciptakan manusia sebagai media komunikasi dan identitas kelompok.Simbol adalah obyek, kejadian, bunyi bicara, atau bentuk-bentuk tertulis yang diberi makna oleh manusia.Bentuk primer dari simbolisasi oleh manusia adalah melalui bahasa.Tetapi manusia juga berkomunikasi dengan menggunakan tanda dan simbol dalam lukisan, tarian, musik, arsitektur, mimik wajah, gerak-gerik, postur tubuh, perhiasan, pakaian, ritus, agama, kekerabatan, nasionalitas, tata ruang, pemilikan barang dan sebagainya.Manusia dapat memberi makna kepada setiap kejadian, tindakan, atau obyek yang berkaitan dengan pikiran, gagasan, dan emosi.Persepsi tentang penggunaan simbol sebagai salah satu ciri signifikan manusia menjadi sasaran kajian yang penting.

Menurut James P. Spradley (1972), simbol merupakan salah satu dari sistem tanda di antara sistem tanda lainnya adalah indeks dan ikon. Simbol, indeks dan ikon masingmasing memiliki ciri-ciri tersendiri, namun indeks(natural-association) dan ikon (formal association) lebih bersifat umum, sedangkan simbol (arbitrary association) memiliki sifat yang lebih khas dan konvensional. Dari sifat-sifat tersebut maka simbol sosial hanya memungkinkan dimengerti oleh anggota masyarakat yang memilikinya. Sebagai suatu media komunikasi yang kongkret atau komunikasi secara verbal maka simbol-simbol tersebut dapat dilihat pada penggunaan gerak isyarat dan kata-kata di dalam bahasa. Tetapi dalam pemanfaatan yang lebih bermakna dan konseptual maka sistem simbol berfungsi sebagai identitas untuk mengikat anggota-anggota dalam suatu komunitas, atau sebagai media integrasi sosial, yang terwujud sebagai sistem nilai, norma ataupun pranata sosial. Adapun pemanfaatan simbol sebagai media komunikasi atau interaksi sosial ini dimungkinkan melalui proses interpretasi. Karena itu manusia tidak hanya akan beradaptasi pada lingkungannya, tetapi juga pada lingkungan simboliknya.Simbolsimbol yang bersifat arbitrary di dalam kebudayaan, maka kebudayaan menjadi bersifat khas dan unik, yang berbeda dengan kebudayaan lainnya.Dalam hal ini maka kebudayaan masyarakat sifatnya menjadi beraneka ragam karena adanya keunikankeunikan di setiap kebudayaan tadi.

Proses simbolisasi yang merupakan proses penciptaan simbol dan tradisi, yaitu uapaya-upaya mengintegrasikan antara simbol-simbol masa lalu dan simbol-simbol modern senantiasa harus selalu dilakukan oleh setiap masyarakat ataupun bangsa. Hal ini untuk menjaga eksistensi masyarakat itu sendiri, misalnya penciptaan bendera merah putih dan Garuda Pancasila, yang diaktualisasikan melalui kegiatan upacara bendera di setiap sekolah dan instansi pemerintah. Pembangunan simbol negara atau kota-kota dalam bentguk tugu peringatan atau patung-patung, yang menampilkan unsur-unsur lama dan baru, juga merupakan proses itu. 


\section{Struktur Kebudayaan}

Koentjaraningrat berpendapat bahwa kebudayaan adalah keseluruhan sistem gagasan, tindakan dan hasil karya manusia dalam rangka kehidupan masyarakat yang dijadikan milik diri manusia yang diperoleh dengan belajar.Selanjutnya beliau mengatakan pula bahwa kebudayaan memiliki struktur yang terdiri dari tujuh unsur kebudayaan universal, yaitu bahasa, sistem pengetahuan, sistem religi, organisasi sosial (sistem politik), mata pencaharian (sistem ekonomi), sistem teknologi dan seni.

\section{Diagran-1 Struktur Kebudayaan}

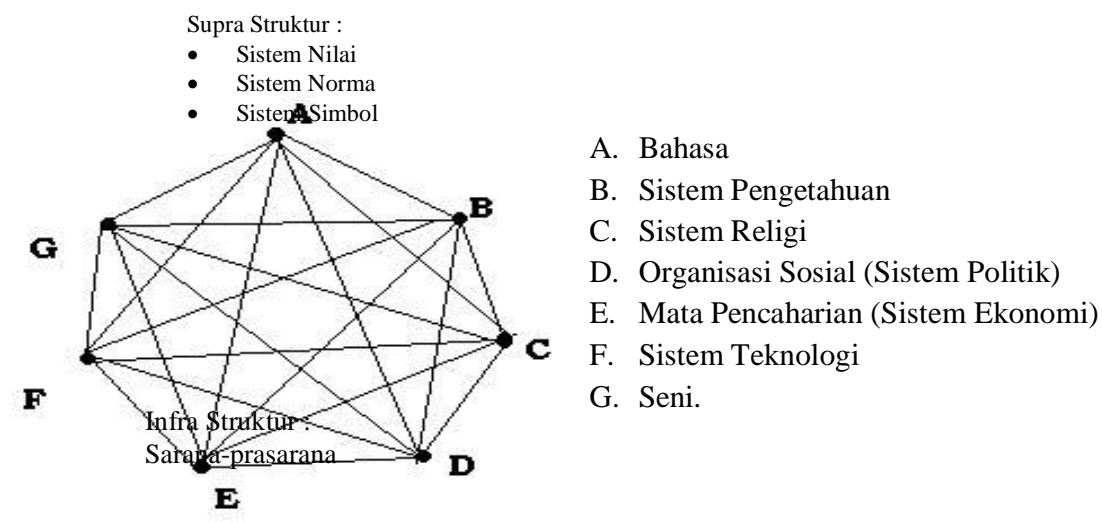

Keseluruhan sistem gagasan ini mengandung pengertian yang sama dengan cipta, rasa dan karsa, yang berlandaskan pada sistem nilai, norma dan simbol, serta berkenaan dengan ke tujuh unsur kebudayaan tersebut di atas. Sistem tindakan atau sistem perilaku merupakan bentuk yang lebih kongkret dan lebih aktif dari sistem gagasan. Selanjutnya sistem gagasan dan tindakan tersebut akan menghasilkan karya-karya kebudayaan yang terlihat bentuknya paling konkret karena berupa benda-benda budaya.

\section{Kepribadian atau Etos Kebudayaan}

\subsection{Kebudayaan dan Kebribadian}

Kebudayaan dapat dijabarkan ke dalam tiga komponen, yaitu komponen biologi, komponen psikologi dan komponen sosial, yang bekerja bersama-sama.Komponen biologi berupa insting dan naluri, komponen psikologi merupakan sifat dan dorongan dasar, kedua komponen ini merupakan komponen dasar atau komponen bawaan manusia dari lahir. Kemudian komponen sosial adalah komponen yang dikembangkan sendiri oleh manusia dalam kelompoknya yang saling berinteraksi, berbentuk nilai-nilai, norma dan simbol. Kesatuan tiga komponen ini secara individual disebut kepribadian seseorang, dan dalam kelompok disebut kepribadian atau kebudayaan masyarakat. Dalam hal ini pengertian kepribadian dan kebudayaan hampir sama yaitu tentang kekhasan, yang membedakan adalah kepribadian termasuk di dalam kata sifat, sedangkan kebudayaan termasuk ke dalam kata benda. Oleh karena itu kepribadian 
merupakan kata sifat yang dapat menerangkan kebudayaan, yaitu watak khas kebudayaan.

Menurut Koentjaraningrat, suatu kebudayaan sering memancarkan suatu watak khas tertentu yang tampak dari luar. Watak inilah yang terlihat oleh orang asing. Watak khas itu sering tampak pada gaya tingkah laku masyarakatnya, kebiasaan-kebiasaannya, maupun dari hasil karya benda mereka.Aspek-aspek simbolik di dalam kebudayaan yang menyebabkan kebudayaan bersifat khas, serta berkenaan dengan komponen psikologi, maka wujud kebudayaan menjadi seperti kepribadian.Adapun yang dimaksud dengan berkepribadian di bidang kebudayaan adalah kebudayaan sebagai pedoman perilaku manusia yang bersifat khas dan bermartabat.

Definisi kepribadian adalah serangkaian karakteristik pemikiran, perasaan, dan perilaku yang berbeda antara tiap individu dan cenderung konsisten dalam setiap waktu dan kondisi. Ada dua aspek dalam definisi itu yaitu, kekhususan dan stabilitas dan konsistensi. Dalam psikoanalisa Freudian tahapan-tahapan perkembangan kepribadian mulai dari oral hingga dewasa. Begitu masa kanak-kanak terlewati dan kepribadian telah terbentuk maka kepribadian adalah cenderung dalam garis konsisten di setiap waktu dan kondisi. Dalam perilaku bahwa kepribadian adalah kumpulan respon-respon kebiasaan. Dalam teori ini kepribadian dipandang cenderung menetap sekalipun ada rentang toleransi respon dalam menyesuaikan stimulus dan reinforcement (reward and punishment) yang mungkin timbul. Dalam teori Humanistik bahwa kepribadian diarahkan oleh pemenuhan level-level kebutuhan dengan puncaknya adalah keberhasikan dalam aktualisasi diri.

Sejalan dengan derasnya arus modernisasi dan globalisasi, budaya-budaya daerah kian memudar dan terpinggirkan oleh budaya-budaya yang masukyang dominan berasal dari budaya barat, sehingga dari akibat tersebut dapat menimbulkan berbagai macam masalah di Indonesia, antara lain adanya perbedaan karakter kepribadian budaya barat dengan budaya Indonesia yang dapat merusak budaya Indonesia yang juga dapat mengakibatkan pembentukan kepribadian yang kurang baik akibat pergeseran nilai-nilai kebudayaan yang ada.

Berbicara mengenai kepribadian dan kebudayaan, tidak terlepas dari hubungan antara masyarakat dan kebudayaan. Masyarakat dan kebudayaan merupakan perwujudan atau abstraksi perilaku manusia. Kepribadian mewujudkan perilaku manusia dan latar belakang perilaku yang ada dalam diri seseorang. Seseorang yang berkepribadian dalam arti yang luas adalah seseorang yang memiliki watak khas, dapat menghargai dan menghormati dirinya sendiri maupun orang lain serta mampu berkomunikasi dengan baik dengan sesamanya dengan kepribadiannya itu.Berkepribadian di bidang kebudayaan dapat diartikan sebagai masyarakat yang yang berkepribadian, dan mampu menghormati dirinya sendiri dan masyarakat lainnya, dapat berkomuniukasi dan berdiplomasi dengan baik dengan masyarakat maupun kebudayaan yang lain.

\subsection{Kebudayan dan Konsep Diri}

Konsep diri adalah inti dari keberadaan individu dan secara naluriah tanpa disadari mempengaruhi setiap pikiran, perasaan dan perilaku individu tersebut.Dua hal yang sering dilakukan untuk mempermudah studi mengenai konsep diri dalam lintas budaya 
adalah konstruk diri individual dan diri kolektif atau (independent construal of self dan interdependent construal of self).

\section{a. Diri Individual}

Diri individual adalah diri yang fokus pada atribut internal yang sifatnya personal, kemampuan individual, inteligensi, sifat kepribadian, dan pilihan-pilihan individual. Diri adalah terpisah dari orang lain dan lingkungan.Mereka didorong untuk membangun konsep akan diri yang terpisah dari orang lain, termasuk dalam kerangka tujuan keberhasilan. Disini nilai kesuksesan dan perasaan akan harga diri membentuk khas individualism. Ketika individu sukses untuk melaksanakan tugas budaya, tidak tergantung pada orang lain, maka mereka lebih puas akan diri mereka dan harga diri mereka meningkat, hal ini dikarenakan berkat usaha keras dari individu tersebut karena mampu mampu menggapainya tanpa bantuan orang lain.

\section{b. Diri kolektif}

Budaya yang menekankan nilai diri kolektif sangat khas dengan ciri perasaan akan keterkaitan antar manusia satu sama lain. Tugas normatif utama pada budaya ini adalah bagaimana individu memenuhi dan memelihara keterikatannya dengan individu lain. Individu diminta menyesuaikan dirinya dengan orang lain atau kelompok untuk mampu membaca dan memahami pikiran perasaan orang lain, bersimpati untuk menempati dan memainkan peran yang telah diberikan. Tugas normatif sepanjang sejarah budaya adalah mendorong saling ketergantungan satu sama lain, sehingga diri (self) lebih fokus pada atribut eksternal termasuk kebutuhan dan harapan-harapannya.

\section{Perubahan Kebudayaan}

Dari waktu ke waktu, dari jaman ke jaman, kebudayaan senantiasa berubah-ubah menyesuaikan dengan kondisi jaman. Perubahan kebudayaan dapat terjadi karena faktorfaktor internal, misalnya dari proses penciptaan (invention), penemuan (discovery) dan inovasi (pembaharuan), serta disebabkan oleh faktor-faktor eksternal, yaitu adanya proses difusi, akulturasi dan asimilasi. Penciptaan dan penemuan dalam berbagai aspek kebudayaan, apabila kemudian disepakati oleh masyarakat, maka akan menjadi bagian dari kebudayaan dan inovasi-inovasi. Komunikasi-komunikasi antar kebudayaan telah menyebabkan terjadinya proses difusi atau menyebarnya unsur-unsur kebudayaan yang kemudian diikuti oleh proses akulturasi, yaitu berintegrasinya unsur-unsur kebudayaan asing dengan sebuah kebudayaan, bahkan terjadinya asimilasi yaitu berintegrasinya unsur-unsur kebudayaan menjadi sebuah kebudayaan yang baru.

Di era globalisasi saat ini kebutuhan dan kepentingan manusia dan masyarakat senantiasa terus berubah, dan komunikasi maupun interaksi antar kebudayaan terus terjadi, maka kebudayaan sebagai perangkat lunak (software) dalam kehidupan manusia juga harus berubah menyesuaikan diri dengan kondisi-kondisi.Clifford Geertz juga pernah mengatakan bahwa kebudayaan adalah serangkaian mekanisme kontrol seperti perangkat lunak (software) di dalam komputer yang terdiri dari instruksi-instruksi, aturan-aturan, rencana-rencana untuk mengatur perilaku. 
Apabila dianalogkan dengan komputer, maka software di dalam komputer itu selalu di upgrademenyesuaikan dengan perkembangan hardware dan penggunaan maupun kepentingan pemakainya. Oleh karenanya kebudayaan itu juga harus selalu berkembang sepanjang masa menyesuaikan dengan perkembangan perilaku dan segala kebutuhan manusia yang terus berubah.Upgrade kebudayaan di sini dapat diartikan sebagai proses revitalisasi dan reaktualisasikebudayaan. Dengan masih minimnya upayaupayarevitalisasi kebudayaan saat ini, maka perubahan-perubahan kebudayaan saat ini juga cenderung berkembang liar, dan inilah yang menyebabkan membudayanya perilaku-perilaku hedonis dan individualis di antara kita. Perilaku KKN, kekerasan dan kejahatan jelas sekali merupakan penyimpangan perilaku budaya, namun kini sangat merebak di negara kita.

Inilah pentingnya upaya-upaya pemerintah untuk merevitalisasi kebudayaan secara sungguh-sungguh, konsisten dan terus menerus.Para budayawan, tokoh-tokoh dan para pakar kebudayaan semestinya diberikan kesempatan seluas-luasnya untuk berfikir dan berdialog tentang kebudayaan serta upaya-upaya revitalisasi dan reaktualisasinya, agar penyimpangan-penyimpangan perilaku budaya tidak menjadi bagian dari kebudayaan seperti kecenderungan sekarang ini.

Agama memang juga memberikan arahan-arahan yang baik bagi perilaku manusia agar tidak terjerumus ke dalam perilaku buruk yang menyesatkan. Namun agama tidak dapat memenuhi semua hal ini, karena agama memang cenderung bersifat dogmatis, sehingga tidak mampu menyelesaikan semua persoalan manusia masa kini. Ketidak mampuan agama ini telah menyebabkan adanya konflik-konflik sosial yang berlatar agama di dunia ini, baik latar agama yang berbeda ataupun konflik antar aliran dalam satu agama.

Inilah pentingnya kebudayaan yang senantiasa harus selalu dikembangkan dan diaktualisasikan untuk mendampingi agama dalam rangka mengarahkan perilaku manusia Indonesia agar tidak terjerumus ke dalam perilaku-perilaku buruk yang ujungujungnya menyebabkan konflik, kekerasan, kejahatan dan disintegrasi bangsa.Dalam hal ini kebudayaan memang memiliki fleksibilitas dalam perubahan-perubahannya, karena lebih bersifat faktualis dan tidak dogmatis.Di sini tentu saja peran Kementerian Pendidikan dan Kebudayaan harus ditingkatkan untuk mendampingi Kementerian Agama dalam membentuk manusia Indonesia agar berperilaku baik, menjalankan perintah agama dan berbudi luhur.Sistem pendidikan nasional tidak hanya diarahkan untuk kepentingan penguasaan ipteks saja, tetapi juga untuk pembentukan karakter bangsa melalui pengembangan kebudayaan.

Pakar prasejarah dan manusia purba Indonesia menyebut bahwa pithecanthropus erectus yang fosilnya banyak ditemukan di situs Sangiran dan beberapa tempat lainnya di Jawa adalah manusia Jawa (Java Man). Menurut pakar, usia manusia Jawa itu sekitar 1,5 juta tahun yang lalu, kemudian apakah Kebudayaan Jawa juga setua itu, dan secara teoritis memang benar. Dengan usia yang setua itu Kebudayaan Jawa memang berkembang dari bentuknya yang sangat sederhana hingga bentuknya seperti sekarang ini. Banyak hal yang telah terjadi dalam perjalanan perkembangan Kebudayaan Jawa. Pengaruh kebudayaan asing dan inovasi-inovasi yang beraneka ragam telah membentuk Kebudayaan Jawa sejak masa lalu.Betapa kuatnya Kebudayaan Jawa itu membendung dan menerima pengaruh kebudayaan asing sepanjang sejarahnya, yaitu kebudayaan Hindu, Budha, Cina, Islam dan Kolonial.Bahkan, kebudayaan asing ini diterima dan 
diakomodasi yang kemudian membentuk Kebudayaan Jawa seperti sekarang ini.Kuatnya Kebudayaan Jawa di masa lalu itu dalam menghadapi pengaruh dan benturan. Saat ini justeru tampak lemahnya Kebudayaan Jawa dalam mengahdapi pengaruh asing dan arus globalisasi.

Sudah tidak ada lagi penjajahan di muka bumi saat ini, dan perang fisik antar negara dan antar kelompok.Namun yang terjadi di era globalisasi saat ini adalah 'perang kebudayaan'.Persaingan-persaingan dan dominasi-dominasi bidang ipteks, politik maupun ekonomi, bahkan juga seni dan bahasa kini sedang berjalan di muka bumi ini. Kondisi seperti ini, kita sebagai orang Jawa wajib mempertahankan Kebudayaan Jawa dalam 'perang kebudayaan ini'. Tetapi,yang terjadi kekalahan sudah tampak di depan mata, seperti masyarakat Indonesia dan Jawa khususnya lebih menyukai seni musik asing dari pada musik tradisional gamelan hingga gaya hidup, sistem politik demokrasi, sistem ekonomi kapitalis dan lain-lain yang berbau asing.Bahkan kata 'tradisional' sekarang sudah kehilangan makna, sebab masyarakat Jawa khususnya memaknai sebagai hal yang kuno dan harus ditinggalkan.

Di era globalisasi terjadi saling mempengaruhi dan mendominasi di bidang kebudayaan, dan hal ini juga tak dapat kita hindari.Yang penting kita harus memperkuat ketahanan budaya, bisa bercermin pula pada sejarah, bagaimana kekuatan Kebudayaan Jawa ini dalam menghadapi masuknya kebudayaan asing, dan dapat diterima tetapi tidak kehilangan jati diri.Bung Karno telah merumuskan Pancasila sebagai dasar negara yang digali dari kebudayaan bangsa ini, tujuannya untuk memperkuat politik kebudayaan Indonesia dalam membentengi diri dari gempuran pengaruh asing dan mendorong bangsa supaya hidup sejahtera, adil dan makmur.

\section{Membangun Jawa Tengah Sebagai Pusat Kebudayaan Jawa}

Dinas Kebudayaan dan Pariwisata Provinsi Jawa Tengah senantiasa harus berupaya secara terus menerus menginventarisasi, mereformulasi, dan merevitalisasi kebudayaan agar masyarakat tidak gagap dan tidak terjerumus ke dalam perilaku buruk yang ujungnya mengarah pada konflik, kekerasan dan kejahatan seperti yang saat ini sedang marak terjadi di Jawa Tengah. Konflik yang terjadi di Kabupaten Batang berkenaan dengan kehadiran PLTU di sana, juga konflik di Kabupaten Kebumen berkenaan dengan perebutan lahan, bahkan konflik di kalangan istana Kasunanan Surakarta.Di samping itu kejahatan perampokan dan penipuan semakin marak. Semua ini karena norma dan nilainilai budaya Jawa khususnya tidak lagi dipahami masyarakat dan tidak sepenuhnya digunakan sebagai pedoman perilaku masyarakat. Oleh karenanya tugas berat bagi masyarakat dan Pemerintah Provinsi Jawa Tengah untuk merevitalisasi Kebudayaan Jawa sebagai warisan leluhur agar digunakan sebagai pedomanperilaku masyarakat sekaligus memperkuat Jawa Tengah sebagai pusat Kebudayaan Jawa.

Tidak salah apabila orang-orang menyebut Kebudayaan Jawa itu adalah kebudayaan yang adiluhung, sebab nilai-nilai budaya yang terkandung di dalamnya memang sangat dalam, sangat bagus dan sangat luas cakupannya.Pengalaman sejarah yang panjang telah membentuk Kebudayaan Jawa adiluhung, baik dalam tatanan sosial, politik, ekonomi maupun religi.Struktur masyarakat Jawa yang berjenjang ini membutuhkan pemahaman yang mendalam bagi masyarakat Jawa sendiri, dan ini 
menunjukkan peran kebudayaan dalam mengatur hubungan antar elemen dalam struktur yang bagus yang sering disebut dengan istilah tata krama.

Sebenarnya amat disayangkan terjadinya konflik kepemimpinan di istana Kasunanan Surakarta.Dalam dunia politik, sebenarnya Kebudayaan Jawa sudah memberikan arahan yang sangat bagus melalui kitab Astabrata, kitab Pustaka Rajya Puwaradan beberapa kitab lainnya yangtersimpan di Keraton Surakarta.Sayangnya paugeran dalam tatanan politik Jawa itu tidak diindahkan oleh para petinggi Keraton Surakarta, akhirnya justeru konflik yang muncul, dan tentu saja dapat merusak citra Kebudayaan Jawa.Mestinya para bangsawan keraton ini harus menjadi ujung tombak dalam pelestarian Kebudayaan Jawa, tidak hanya pada tataran tradisi dan seni budaya saja, tetapi juga menyangkut aspek budaya politik seperti yang sudah dinyatakan dalam paugeran keraton.

Sudah pada tempatnya apabila pusat Kebudayaan Jawa itu berada di Jawa Tengah, karena di wilayah ini ada Keraton Kasunanan Surakarta, merupakan keraton pertama dan yang paling besar sebagai pewaris Kasultanan Mataram Islam sebelum pecah menjadi empat keraton.Jawa Tengah harus berperan menjadi pusat pelestarian dan pengembangan Kebudayaan Jawa dalam segala aspek budaya, baik tradisi religius, seni, politik, pengetahuan dan ekonomi.

Pelestarian Kebudayaan Jawa sangat diperlukan di segala aspeknya, sebab Kebudayaan Jawa ini dapat menjadi pegangan masyarakat Jawa, khususnya masyarakat Jawa Tengah dalam rangka menghadapi arus globalisasi dan berinteraksi dengan kebudayaan asing. Sebagai contoh, masyarakat Jepang dan Korea Selatan sangat gigih mempertahankan, melestarikan dan mengembangkan kebudayaannya untuk menghadapi arus globalisasi dan pengaruh asing itu dan hasilnya bangsa Jepang dan Korea sekarang menjadi bangsa yang kuat, modern dan maju. Pengalaman negara lain ini kiranya dapat diadopsi oleh Pemerintah Provinsi Jawa Tengah untuk memperkuat dan melembagakan Kebudayaan Jawa sebagai pegangan masyarakat Jawa Tengah dalam menghadapi arus globalisasi.

Arus globalisasi adalah arus asing atau arus dari luar dari berbagai penjuru dunia yang masuk ke Indonesia.Untuk suatu kemajuan Indonesia memang memerlukan pengetahuan baru dan inovasi tentang berbagai aspek terutama yang berkaitan dengan ipteks, permodalan dan industri.Kebutuhan ini diperoleh dari negara asing, terutama dari barat.Namun kebutuhan seperti ini tidak mungkin terlepas dari keseluruhan kebudayaan asing yang masuk, sebab kebudayaan itu terintegrasi secara utuh baik yang bersifat baik maupun buruk dari prespektif ke-Indonesiaan.Oleh karenanya untuk menghadapi hal ini, maka kebudayaan sendiri harus diperkuat untuk menghadapi masuknya kebudayaan asing tersebut, sehingga akulturasi kebudayaan dapat berjalan secara simultan dan dapat diterima oleh semua pihak. Selama ini baik yang terjadi di Jawa Tengah khususnya dan di Indonesia pada umumnya, kebudayaan Jawa maupun kebudayaan nasional sangat lemah menghadapi masuknya kebudayaan asing. Akibatnya fenomena asing saat ini sangat mewarnai perilaku masyarakat Indonesia, dan cenderung menggeser dan merusak kearifan lokal dan kebudayaan nasional. Semua negara di dunia ini akan memperkuat kebudayaannya sendiri-sendiri dalam mengahadapi arus globalisasi, agar tidak tergerus arus itu. Dalam hal ini Indonesia dan Jawa Tengah tentunya juga harus berbuat yang sama, yaitu memperkuat kebudayaannya untuk menghadapi arus itu. 
Agama dan kebudayaan saling melengkapi dan saling mengisi sebagai pedoman perilaku. Agama Islam yang dipeluk oleh sebagian besar masyarakat Jawa sangat mewarnai Kebudayaan Jawa, demikian halnya di sini Kebudayaan Jawa juga mewarnai agama Islam.Oleh karenanya,agama dan kebudayaan merupakan satu kesatuan pedoman perilaku masyarakat Jawa dalam rangka hubungan antar manusia dan manusia dengan Tuhannya. Selain Islam, Kebudayaan Jawa juga cukup akomodatif berkolaborasi dengan agama lain seperti agama Katolik dan Kristen, bahkan beberapa aliran Kristen menggunakan bahasa Jawa. Agama Hindu dan Budha juga cukup akomodatif, sebab kedua agama ini juga mewarnai terbentuknya Kebudayaan Jawa.

\section{Diagram-2 Kebudayaan Jawa dalam pengaruh tekanan Arus Globalisasi}

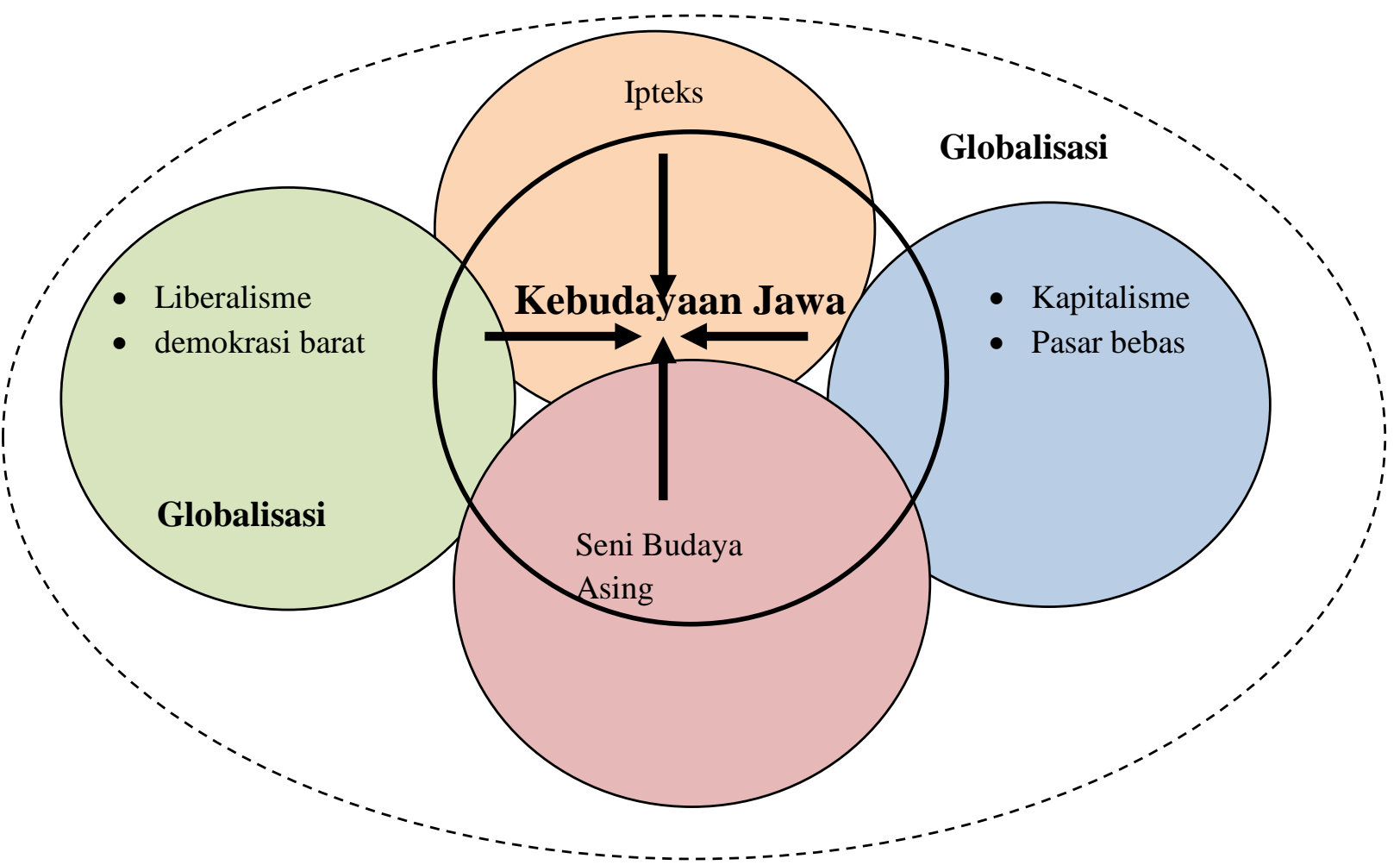




\section{Diagram-3 Kebudayaan Jawa harus dapat mengatasi pengaruh Arus Globalisasi}

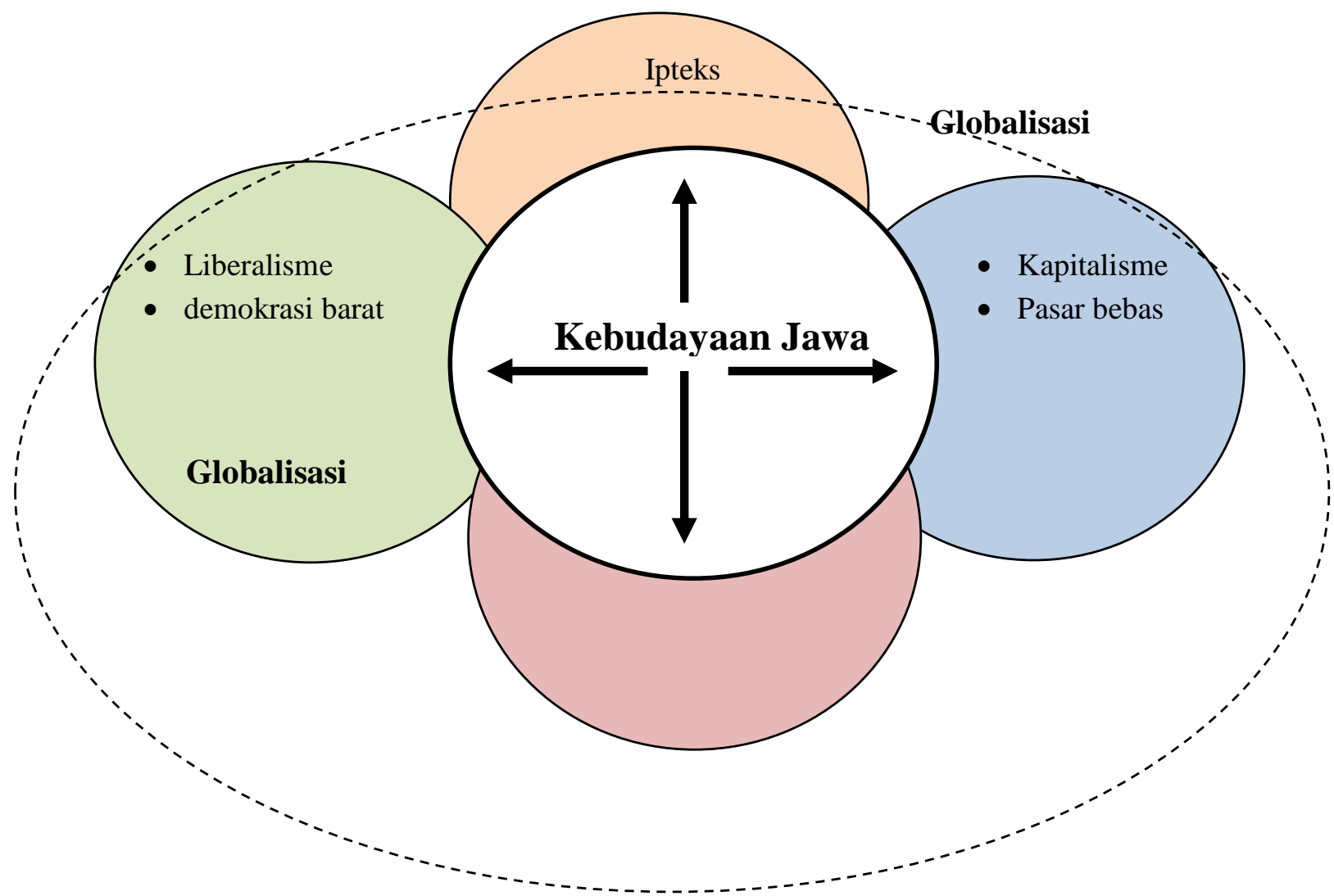

Dalam rangka membangun dan mengembangkan Kebudayaan Jawa dilakukan dengan merevitalisasi norma dan nilai budaya yang kemudian diterapkan pada ke tujuh unsur budaya universal, yaitu bahasa, sistem perekonomian, sistem organisasi sosial atau politik, sistem pengetahuan, teknologi, agama serta seni budaya.Didalam sistem politik, Ki Hajar Dewantoro pernah mengajarkan tentang politik kepemimpinan Jawa dengan konsep "ing ngarsa sung tulada, ing madya mangun karsa, tut wuri handayani". Artinya sebagai seorang pemimpin di depan harus dapat memberi teladan, di tengah-tengah masyarakat harus dapat berbuat/berkreasi, dan di belakang harus bisa mendampingi dan mendorong. Dalam hal ini pemimpin negara juga harus dapat mewujudkan konsep negara yang "tata titi tentrem kerta raharja", artinya negara dan pemerintah harus menjamin keteraturan dan keamanan menuju masyarakat yang adil makmur.Ada pula konsep budaya Jawa lainnya seperti "manghayu hayuning bawana", artinya menjaga kesimbangan dunia.

Visi Gubernur Jawa Tengah menggunakan konsep “Tri Sakti” Bung Karno, yaitu "berdaulat di bidang politik, berdikari di bidang ekonomi, dan berkepribadian di bidang kebudayaan".Konsep berkepribadian di bidang kebudayaan, masyarakat Jawa Tengah harus memiliki kebudayaan yang kuat dan berkarakter.

Berkenaan dengan "Pidato Kebudayaan" Gubernur Jawa Tengah yang sampaikan pada tanggal 6 Januari 2014 yang lalu dengan topik “Wiwitan Makarya Damel 2014 Jawa 
Tengah Sejahtera Berdikari".Dalam pidato itu tercermin betapa beliau menggunakan Kebudayaan Jawa dalam menjalankan tugasnya sebagai gubernur, mengingat rakyat Jawa Tengah adalah mayoritas orang Jawa.Tradisi "tedhak sinten" digunakan sebagai cermin untuk mengawali masa tugasnya, sementara rembugan, sambatan dan gotong royong dijadikan sebagai model untuk bekerja dan memecahkan persoalan-persoalan di Jawa Tengah.

Walaupun demikian perlu diingat bahwa masyarakat Jawa itu bersifat paternalistik, oleh karenanya, seorang pemimpin juga harus dapat memberi bimbingan, keteladanan, dan pengayoman bagi masyarakat.Tidak salah apabila Ki Hajar Dewantoro memberikan konsep kepemimpinan Jawa itu sebenarnya juga bersifat paternalistik.Visi Gubernur Jawa Tengah menggunakan konsep "Tri Sakti" Bung Karno, yaitu "berdaulat di bidang politik, berdikari di bidang ekonomi, dan berkepribadian di bidang kebudayaan", yang dikemas dengan slogan "mboten ngapusi" dan "mboten korupsi". Berkenaan dengan kondisi saat ini di masyarakat justeru "ngapusi" dan "korupsi", yang menunjukkan bahwa betapa kebudayaan Jawa yang adhiluhung itu sudah rusak, karena masyarakat Jawa sudah membiasakan diri dengan penyimpangan dengan ngapusi dan korupsi itu. Semoga slogan yang diberikan oleh Gubernur Jawa Tengah itu dapat memberikan contoh dan mengembalikan masyarakat Jawa agar kembali kepada kebudayaannya dengan memahami konsep tata krama, tata susila dan unggah-ungguh.

\section{Trilogi Soekarno dan konteks ke Jawatengahan}

berdaulat di bidang politik,

berdikari di bidang ekonomi, dan

berkepribadian di bidang budaya.

Demikian konsep Trilogi Soekarno tersebut dapat digarap dengan strategi jangka pendek, menengah, panjangmelalui kebudayaan dalam arti luas harus memperbaiki tiga hal mendasar yakni: 1 . Pendidikan yang menghasilkan pemikiran dan pengetahuan 2 . Perilaku yang mewujud dari hasil sebuah pengetahuan 3. Menghasilkan produk yang berkualitas yang merupakan hasil dari cara berpikir dan berperilaku.

Untuk itu yang perlu diingat adalah, jabatan gubernur 5 tahunan, maka trilogi harus berjalan secara signifikan dan relevan, antara lain: (1) Gubernur tetap harus jeli dan sensitif melihat SWOT kebudayaan masyarakat Jawa Tengah, sekaligus peka terhadap isu nasional ataupun internasional yang bisa menjadi pemicu kerja yang signifikan dan relevan. Dan sadar bahwa kebudayaan membutuhkan arah dasar. (2) Inti dari 'mboten korupsi - mboten ngapusi' adalah (a) memanfaatkan sumberdaya (alam, manusia, budaya) untuk kemaslahatan manusia, dan (b) kejujuran sebagai sikap yang membentuk rasa keadilan. (3) Maka rumusan implementasi trilogi harus menjadi arah dasar Jawa Tengah dengan menerapkan: DAULAT POLITIK > tercermin dalam arah politik 5 tahun ke depan: mangkus (efektif) dan sangkil (efisien) > 'rembugan' yang jelas (masalahnya jelas, cara berkomunikasinya jelas, bahasanya jelas, rekan bicaranya juga harus jelas $>$ supaya seimbang. Maka peran pejabat menjadi signifikan saat bicara dengan rakyat > contoh ketika pejabat berkomunikasi dengan masyarakat bahasanya 'tidak boleh njlimet'. Pejabat (eksekutif) harus bisa menjelaskan dengan alasan yang jelas tentang nilai penting (significant values) semua program dan kegiatan. Maka bentuk politik yang 
berdaulat (program dan kegiatan apapun) tercermin dalam lancar dan terserapnya dana pembangunan secara tepat waktu, tepat mutu dan tepat sasaran (cermin lancarnya roda budaya 'rembugan' antara rakyat - wakil rakyat/DPR - kepala daerah).

BERDIKARI DI BIDANG EKONOMI > harus tercermin dari kebijakan seorang Gubernur, dimulai dari anggaran yang turun pada tahun 2014, manfaatkan untuk meyakinkan rakyat bahwa 5 tahun ke depan kualitas ekonomi setiap keluarga jawa tengah membaik dan menuju ke arah yang benar. >mampu berdiri di atas kaki sendiri, sebagai perwujudan > karena perilaku mangkus dan sangkil maka mampu untuk berdikari.

BERKEPRIBADIAN > memiliki karakter unggul yang tercermin dalam kemampuan mengolah dan menumbuhkembangkan budaya jawa ditengah-tengah situasi kesejagadan (globalisasi). Tidak larut tapi tumbuh bersama melalui seleksi budaya asing.

Selain itu, (4) Revitalisasi yang berdampak transformasi, artinya: dalam 5 tahun ke depan gubernur harus mengolah semua sumberdaya (membuat vitalitas baru bagi alam, manusia, budaya) secara cerdas dan bernas, melalui aksi yang strategis, yakni : (1) membuat contoh aksi politik yang berdaulat; (2) membuat contoh sikap hidup berdikari secara ekonomi; dan (3) membuat contoh sikap masyarakat yang berkepribadian

\section{Gambar-1 Pusat-pusat Pengaruh dan Persebaran Pengaruh}

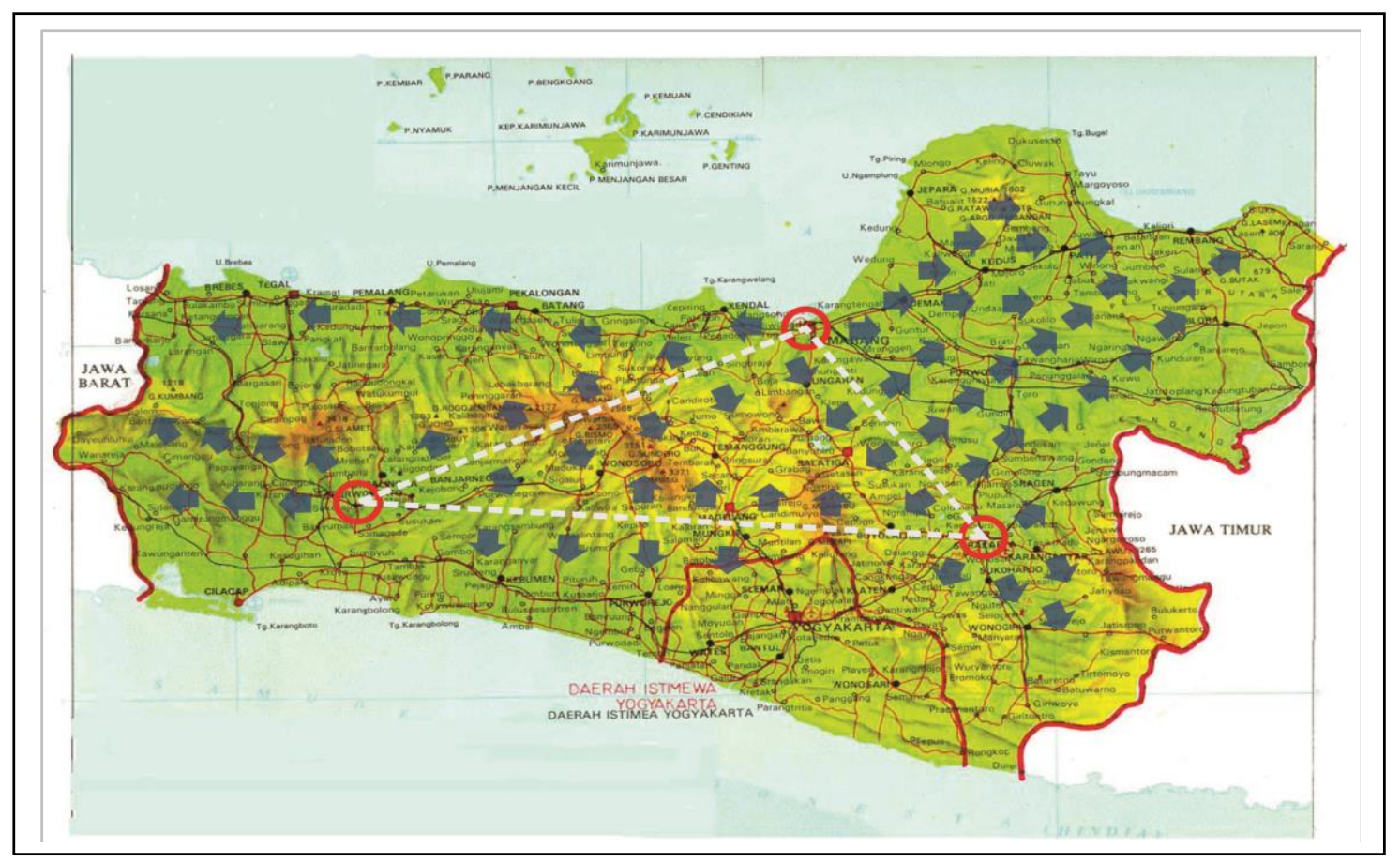

Gambar-1 di atas menunjukkan persebaran pengaruh Kebudayaan Jawa dari pusatpusatnya pada kondisi saat ini. Ada tiga pusat Kebudayaan Jawa saat ini yaitu Semarang sebagai pusat Kebudayaan Jawa Pesisiran, Surakarta sebagai pusat Kebudayaan Jawa Keraton, dan Banyumas sebagai pusat Kebudayaan Jawa Banyumasan. Harus diakui juga 
bahwa Kota Surakarta merupakan pusat dari ketiganya, sebab di sana ada Keraton Surakarta sebagai warisan dari Kerajaan Mataram pembentuk Kebudayaan Jawa itu.

\section{G. Analisis Swot}

Dalam rangka membenahi Kebudayaan Jawa agar dapat berfungsi efektif sebagai pedoman perilaku masyarakat Jawa Tengah, maka Kebudayaan Jawa ini perlu dievaluasi menggunakan analisis Swot sebagai pegangan bagi budayawan, pelaku budaya, ilmuwan kebudayaan dan pemerintah, khususnya Pemerintah Provinsi Jawa Tengah. Walaupun terasa agak aneh, namun ternyata banyak urgensinya dengan melakukan analisis swot terhadap Kebudayaan Jawa, sebab secara tidak langsung Kebudayaan Jawa ini memang terkena dampak buruk yang cukup signifikan dari arus globalisasi dan perkembangan ekonomi pasar bebas. Reinventarisasi dan revitalisasi Kebudayaan Jawa memang sangat urgen untuk diterapkan, sebab perilaku-perilaku buruk sudah menjangkiti masyarakat Jawa Tengah.

Analisis swot merupakan upaya untuk mengurai permasalahan yang terjadi pada Kebudayaan Jawa, mencakup aspek kekuatan (strength), kelemahan (weakness), peluang (opportunity) dan tantangan/ancaman (threat). Dengan analisis swot ini dapat diketahui secara lebih detail permasalahan kebudayaan Jawa, dan untuk ke depan dapat pula dilakukan analisis berikutnya yaitu analisisn esfas dan isfas yang merupakan penajaman dari analisis swot.

Untuk lebih rinci dalam menganalisis swot Kebudaaan Jawa, maka selain empat aspek swot itu, juga menggunakan teori tujuh unsur kebudayaan universal seperti disampaikan oleh Prof.Dr. Koentjaraningrat dan para pakar kebudayaan lainnya.Pertama adalah bahasa Jawa, kekuatan (strength) bahasa sebagai media komunikasi yang membentuk sikap yang tau tata karma, njawani santun, andap asor, lembah manah, ramah, semanak.

Komunikasi secara adat secara resmi antar warga masyarakat Jawa juga masih sering menggunakan basa Jawa kromo inggil ini, yang harus diucapkan secara sopan dan halus.Namun sayangnya basa kromo inggil ini sudah jarang digunakan, ini menunjukkan terkikisnya kebudayaan Jawa. Kelemahannya, Belum optimalnya penggunaan bahasa jawa dalam keseharian dengan benar

Peluang dalam bahasa jawa mampu membentuk jati diri sebagai orang jawa, dan nilai budaya Jawa ini dapat ditingkatkan penggunaannya dengan meningkatkan kehalusan dan kesopanan dalam berbahasa untuk menyelesaikan segala permasalahan manusia.Tentu saja kebaikan dan kejujuran harus diutamakan dalam komunikasi antar warga masyarakat Jawa.Arus globalisasi juga mengancam dan sekaligus menjadi tantangan dalam upaya merevitalisasi bahasa dan nilai budaya Jawa, serta kebudayaan Jawa secara keseluruhan.Dalam hal ini bahasa dan nilai budaya harus diperkuat agar mampu menyerap arus yang baik dan membuang arus yang buruk, dan kurang konsistensi penggunaan bahasa jawa dalam keseharian.

Selanjutnya pada unsur sistem pengetahuan, kekuatan Kebudayaan Jawa pada kandungan kebudayaan pada pengetahuan tentang agama, kepercayaan, kosmologis, pertanian dan tentang alam lainnya.Kelemahannya pengetahuan budaya ini sering dianggap sebagai pengetahuan tradisional dan kuno.Peluangnya pengetahuan ini dapat diitegrasikan dengan pengetahuan modern, yang sekaligus merupakan ancaman atau 
tantangan.Era industrialisasi ini juga merupakan ancaman dan tantangan untuk diitegrasikan dengan kebudayaan Jawa, agar kebudayaan Jawa ini tidak dianggap kuno.

Unsur teknologi dalam kebudayaan Jawa sudah ada dalam teknologi pertanian, nelayan dan bangunan. Teknologi pertanian sudah menghasilkan produk-produk pertanian dari tanah Jawa, terutama beras. Sejak masa Candi Borobudur, kemudian masa kerajaan Majapahit dan kerajaan Demak, Jawa merupakan sumber hasil pertanian ekspor, terutama beras. Sumber-sumber sejarah menunjukkan akan hal itu, bahwa Jawa merupakan penghasil beras ekspor. Catatan Belanda pada abad ke-19 hingga awal abad ke-20 Pulau Jawa merupakan penghasil gula terbesar kedua dunia di samping juga pengekspor kopi, kapas dan kayu jati.Di samping itu teknologi bangunan tradisional Jawa cukup bagus dan unik, berupa bangunan joglo, limasan dan tajug masjidan.Sejarah juga membuktikan bahwa candi Borobudur dan candi Prambanan merupakan puncak hasil teknologi bangunan Jawa di masa lalu. Teknologi pelayaran juga tercatat dalam sejarah, Jung Jawa merupakan kapal-kapal layar Jawa yang cukup besar, dan sejaman dengan candi Borobudur, di candi ini juga terdapat relief kapal bercadik dalam ukuran besar yang dapat berlayar hingga Madagaskar. Sistem teknologi Jawa tersebut sekarang seperti terlupakan, merupakan kelemahan karena dianggap tradisional dan sudah kuno. Peluangnya sebenarnya teknologi Jawa dapat diitegrasikan dengan teknologi maju.Seperti bangsa Jepang yang mengimpor teknologi Eropa-Amerika yang kemudian diadopsi menjadi teknologi Jepang yang menghasilkan produk-produk industri modern.Tantangannya di Jawa adalah keterbatasan SDM untuk dapat mengadopsi teknologi modern diintegrasikan dengan teknologi Jawa.

Sistem organisasi sosial atau sistem politik di Jawa sudah muncul sejak sekitar abad ke-5 Masehi hingga kerajaan Mataram dalam bentuk sistem politik kerajaan.Dalam sistem politik ini sebenarnya ada beberapa kitab dari jaman kerajaan mataram yang dapat digunakan sebagai acuan politik kerajaan dan masyarakat Jawa untuk mencapai keharmonisan hubungan dan tatanan masyarakat Jawa.Aspek demokrasi dengan musyawarah dan mufakat merupakan landasan politik Jawa yang kemudian diadopsi di dalam Pancasila.Kelemahannya sistem politik Jawa ini adalah sifatnya yang paternalistik dan struktural yang sering dipandang sifat yang negatif.Peluangnya, pemerintah dan masyarakat harus dapat mengubah sifat negative politik Jawa tersebut menjadi hal yang positif.Apa yang pernah diucapkan oleh Ki Hajar Dewantoro dengan konsep ing ngarsa sung tulada, ing madya mangun karsa, tut wuri handayani, merupakan aspek yang positif terhadap politik paternalistik dan struktural. Ancaman yang ada adalah demokrasi liberal yang saat ini tampaknya ditelan mentah-mentah digunakan dalam kehidupan politik.One man one votesekarang justeru menjadi anadalan sistem politik, pada hal seharusnya dipakai dalam kondisi yang terpaksa dan sangat krusial.

Sistem matapencaharian atau sistem ekonomi Jawa kekuatannya adalah bidang pertanian, sebab sesuai dengan kebudayaan Jawa ini mainstreamnya adalah kebudayaan agrikultur.Produk-produk pertanian dan perkebunan Jawa berupa beras, gula, kopi, kapas dan kayu jati pernah menjadi pemasok utama kebutuhan dunia di masa lalu.Kelemahannya saat ini produk-produk andalan tersebut justeru berbalik menjadi produk impor.Peluangnya tentu saja bagaimana mengubah produk-produk pangan tersebut menjadi produk ekspor lagi, dan mungkin juga harus dilakukan dengan manajemen industri pertanian agroindustri).Ancamannya tentu saja adalah sistem pasar bebas dan sistem kapitalisme yang saat ini diterapkan oleh masyarakat Jawa. 
Sitem religi Jawa, kekuatannya berhasil mengadopsi agama-agama besar di dunia seperti Agama Hindu, Budha, Islam, Katolik dan Protestan. Kekuatan ini telah menciptakan masyarakat Jawa bertoleransi terhadap lima agama besar tersebut, walaupun saat ini agama Islam mendominasi baik secara kuantitas maupun kualitas dalam kebudayaan Jawa. Kelemahannya, bahwa agama-agama besar tersebut kadangkadang menunjukkan sektarian dan eksklusivitasnya yang tentu saja bertentangan dengan toleransi.Peluangnya, kita harus dapat membuat agama-agama besar tersebut bersifat inklusif dan bertoleransi terhadap semua agama dan kepercayaan yang ada.Ancamannya adalah kehidupan sekularime dan materialism saat ini yang sedang merebak, juga ekslusifisme yang dapat memicu konflik yang berbau SARA.

Kesenian Jawa, kekuatannya terletak pada keanekaragamnya kesenian tradisional, baik yang berbentuk seni istana (keraton) dan seni tradisi rakyat, baik yang bersifat tangible maupun intangible. Seni tari-tarian, vocal dan karawitan merupakan seni tak benda (intangible), sedangkan seni bangunan dan kerajinan merupakan seni yang bersifat kebendaan (tangible). Betapa tingginya mutu kesenian Jawa ini dan sering mendapat penghargaan internasional, bahkan candi, batik dan keris sudah menjadi warisan dunia.Kelemahannya kesenian Jawa ini semakin ditinggalkan oleh pendukungnya sendiri masyarakat Jawa, sehingga terutama generasi muda lebih menyukai seni modern yang berbau asing dari pada seni tradisi milik kita sendiri.Peluangnya seni tradisional Jawa ini harus kita cintai sepenuhnya sebelum kita menyukai seni modern, karena secara kualitas seni tradisi Jawa tidak kalah dengan seni modern. Ancamannya adalah gempuran seni modern yang berbau asing itu sendiri.Banyaknya warisan dunia, khususnya bidang seni yang berada di Jawa Tengah, maka perlu dikelola secara khusus oleh Pemerintah Provinsi Jawa Tengah dengan membentuk lembaga khusus pelestari dan pengelola warisan dunia di Jawa Tengah. Tujuannya agar warisan dunia di Jawa Tengah terpelihara dengan baik dan tidak tercoret dari daftar di Unesco, serta mengkaji kemungkinan produk-produk budaya lainnya yang cukup potensial di Jawa Tengah menjadi warisan dunia yang baru, seperti misalnya Kota lama di Semarang, Masjid Agung Demak, atau yang lainnya.

\section{Simpulan}

Karakter masyarakat saat ini sudah sangat krisis, karena sudah meninggalkan nilainilai budaya lokal seperti budaya Jawa. Sikap unggah-ungguh, tepa slira, gotong royong, andap asor, semanak, sak yeg sak ekapraya sudah tidak banyak dipahami oleh orang-orang Jawa. Sikap itu sebenarnya memiliki makna kebersamaan yang tinggi di antara anggota masyarakat Jawa, khususnya dalam kehidupan sosial dan saling menghargai satu sama lain.

Kondisi masyarakat Jawa sekarang sudah bersifat lebih individual, materialistis, dan lebih mendahulukan kepentingannya sendiri dari pada kepentingan bersama, kurangnya toleransi terhadap sesama, ingin cepat kaya dengan menghalalkan segala cara, juga kekerasan dan kejahatan semakin meningkat di mana-mana. Aspek kekuasaan dan aspek ekonomi menjadi sangat dominan dalam orientasi kehidupan masyarakat, yang seharusnya hanyalah merupakan sarana kehidupan bersama. Akibatnya masyarakat saat ini cenderung memburu harta dan kekuasaan dengan menghalalkan segala cara, ketidakpedulian, serta meninggalkan gotong royong dan toleransi. 
Program trilogi Soekarno yang diterapkan Gubernur Jawa Tengah dengan tambahan slogan "ora ngapusi" dan "ora korupsi", semoga dapat dihayati oleh masyarakat Jawa Tengah, khususnya untuk memperbaiki pemahaman masyarakat terhadap kebudayaannya yang adhilugung itu. Di samping itu, dengan bantuan analisis swot semoga Pemerintah Provinsi Jawa Tengah dapat membangun dan merevitalisasi Kebudayaan Jawa untuk digunakan sebagai acuan perilaku dan kehidupan bersama masyarakat Jawa Tengah berkenaan dengan pembangunan karakter bangsa.

\section{Daftar Pustaka}

Ahimsa-Putra, Sri, Hedi. 2001. Strukturalisme Levi-Strauss: Mitos dan Karya Sastra. Yogyakarta : Galang Printika.

Christomy, T, \& Yuwono, Untung (Peny). 2004. Semiotika Budaya. Depok: Puslit Kemasy \& Budaya Direktorat Riset dan Pengabdian Masyarakat Univ. Indonesia. Memuat karangan Benny H. Hoed, Rahayu S, Hidayat, Yasraf Amir Piliang, T. Cristomy dll.

Geertz, Clifford. 1973. The Interpretation of Culture. New York : Basic Books 1983. Local Knowlegde: Further Essay in Interpretive Anthropology. New York: Basic Books.

Handler, Richard \& Linnekin, Jocelyn. 1984. "Tradition: Genuine or Spurious", dalam Journal of American Folklore, vol. 97 . No.385 by The American Folklore Society 0021-8715/84/3850273-1852.30/1, hal. 273-290.

Harsoyo. 1988. Pengantar Antropologi. Bandung : Binacipta.

Hobsbawm, Eric \& Terence Ranger. 1987. The Invention of Tradition. London-New YorkSidney: Cambridge University Press.

Koentjaraningrat. 1985. Pengantar Antropologi. Jakarta : Aksara Baru.

Rapoport, Amos. 1969. House Form and Culture. London: Prentice-Hall International, Inc.

Saiffudin, Achmad Fedyani. 2005. Antropologi Kontemporer : Suatu Pengantar Kritis Mengenai Paradigma. Jakarta : Prenada Media.

Spradley, James P. 1972. Culture and Cognition: Rules, Maps and Plans. New York : Chandler Publishing Company. 